\title{
10 Actor roles and practices in energy transitions
}

\author{
Perspectives from Finnish \\ housing cooperatives
}

Senja Laakso and Jani Lukkarinen

\section{Introduction}

Housing sector represents a huge potential - as well as a major challenge - in efforts to achieve a carbon neutral society. In Finland, the housing-related practices are responsible for $20 \%$ of total energy use and for one-third share of the carbon footprint of an average resident, the major share coming from heating. Much of the existing building stock will go through renovations in the coming decades and the decarbonising energy system requires more demand response capacity, dispersed production and energy storages. It is thus essential to understand how to accelerate the shift towards renewable energy, as well as energy efficiency and sufficiency, in homes.

Despite apartment buildings accommodating one-third of Finland's population, they have become the focus of energy policy only recently (Kivimaa et al., 2020). Several recent, cross-sectoral policy developments position housing cooperatives at the forefront of energy policy. The Ministry of Economics and Employment of Finland commissioned a Smart grid taskforce in 2016 to coordinate activities in the implementation of the $\mathrm{EU}$ energy community legislation (Pahkala et al., 2018). The work led to legislative reforms that ease rules for the energy micro production and required energy companies to enable the sharing of produced electricity in the energy communities, such as housing cooperatives, without extra fees. Further, the State Energy Authority enrolled a network of regional energy experts to provide more hands-on advice on the period between 2019 and 2023, and Energy Aid Program for housing was launched in 2020 by the Ministry of Environment. Both actions aim to push energy actions on the grassroots level. Finally, the new Building Renovation programme 2020-2050 mandated by the $\mathrm{EU}$ aims at coordinating building energy activities and provides support across the country. On the local level, networks of cities and municipalities, such as the national network of Carbon neutral municipalities (CANEMURE), are engaged in experimentation and piloting sustainable energy use in buildings (Heiskanen et al., 2017).

Housing cooperatives ${ }^{1}$ are at the centre of implementing climate policies for the building sector, as they are a dominant form of governing residential building stock. However, the policy designs and developments often miss the 
residents, who form the central decision-making body that should be engaged in the sustainable energy activities and whose everyday consumption practices steer the energy demand in buildings. We suggest that better policy implementation requires a practice-based understanding of these dynamics. Previous research exists on the ways the material conditions, ownership structures and decisionmaking dynamics of housing affect the long-term development and implementation of the energy policies for buildings (e.g., Kivimaa and Kern, 2016). Research also exists on the roles of professionals as intermediaries in transitions (e.g., Kyrö et al., 2012; Lazarevic et al., 2019; Peltomaa et al., 2020), the interplay between novel technologies or building physics and user practices (Gram-Hanssen, 2011; Strengers, 2012; Wolff et al., 2017) and professional practices in the building sector (Gram-Hanssen et al., 2017; Macrorie et al., 2015; Shaw and Ozaki, 2016), while less has been said about the practices in housing cooperatives and how actors reproduce and reconfigure these practices.

This chapter presents the findings of a study, in which we interviewed key actors - property managers, board members and residents - in eight Finnish housing cooperatives engaged in sustainable energy projects. The objective of our study was to utilise practice-theoretical approaches to uncover (1) what are the practices either supporting or preventing engagement with sustainable energy in housing cooperatives and (2) how do people conceive these practices and their agency for changing practices towards sustainability. The findings provide insights for the reconfiguration of housing practices by linking systems of politics, education, planning, management and housing more closely together.

In the following sections, we outline the theoretical and methodological premises of the study. Then, we present the results and provide concluding thoughts in the final section.

\section{Conceptual framework}

Practice theories are much used in sustainable consumption research, yet they are applicable to many domains of activity (Schatzki, 2015; Welch and Yates, 2018). In the housing sector, Guy and Shove (2000) have emphasised the importance of understanding cultural and social engagements when energy-efficiency decisions are made in building research, design and construction. Also, Karvonen (2013) has employed practice theory in analysing the complexity of community-based domestic retrofit programmes. In their study on heat pumps, Gram-Hanssen et al. (2017) highlight the need for improved communication between professionals and residents in embedding new technologies in everyday practices. Incumbent regime practices in different areas, for example, the energy company business models, operations of construction and renovation companies, and education for building maintenance and management specialists, as well as asymmetric information between the different actors, non-functional regulation and incentive structure and lack of technical expertise, have been identified as barriers for shifting energy practices (e.g., Macrorie et al., 2015; Palm, 2013; Palm and Reindl, 2018; Shaw and Ozaki, 2016). 
According to Strengers (2012), practice theories overcome "common dualisms" manifesting themselves in the energy sector, such as supply and demand, consumption and production, and behaviour and technology. In practice theories, the focus shifts from autonomous agents, structures or technologies, onto practices reproduced through daily performances. Until recently, theories of practice have said relatively little about people in their emphasis to serve as a "middle-range theory" (Schatzki, 2017, p. 26). According to Shove and Pantzar (2005), individuals hold a very specific role in practice theories as "carriers" or "performers," who are both "captured" by practices and reproduce them through their actions. In addition to individuals holding the potential to alter the practices, participants in particular practices occupy particular roles and positions - different ways of carrying on a set of practices and being someone of a given sort in them (Schatzki, 2017). These roles comprise partially overlapping and partially divergent understandings of these practices and skills to perform them.

As Strengers (2012) notes, the practice approach also acknowledges the agency of other than human actors: for example, new technologies, such as air conditioning or heat pumps can bring changes into practices and hold them together, while the limitations of the existing building stock or the energy infrastructure can make the practices rather constant. While studying the role of professionals in implementing sustainable building code in the UK, Shaw and Ozaki (2016) noted how technologies participate in reconstituting existing activities and relations, acting "to unite means and ends" (sometimes with undesired outcomes). They use the example of solar photovoltaic technology, in which the housing cooperatives were able to maintain their jurisdiction as housing landlords and existing relationships with tenants and energy suppliers. The combined biomass heat-andpower $(\mathrm{CHP})$ technology, in turn, required the housing cooperative to register as a utility provider and build new practices, such as sourcing energy, supplying fuel and billing residents for energy consumption. In the contrasting cases, the technologies were strategically mobilised to keep in place or reconfigure practices.

Overall, the housing cooperatives can be seen as key players in the energy system transition on three levels. On the level of energy systems, the building stock has a large demand response and dispersed production capacity that can be utilised in the networked system by utilising diverse enabling technologies. On the project level, the housing cooperatives can mobilise investments in novel energy services and smart energy technologies that reduce the demand for fossil fuels and lower the carbon footprint. On the level of everyday interactions, the housing cooperatives are facilitators of different constellations of energy-related practices that might transform the energy consumption patterns. All three levels are relevant, when considering political activation of the housing cooperatives, although our analysis focuses mainly on the last two.

\section{Materials and methods}

In our study, we focus on the critical practices for sustainable energy transition in the housing sector and various roles the actors can take in these practices, by 


\section{Senja Laakso and Jani Lukkarinen}

interviewing the key actors in eight Finnish housing cooperatives. The key actors in the housing cooperatives are the residents (of which those who own their property are also shareholders) and the board members elected by the annual meeting of the shareholders. In addition, a professional property manager oversees the day-to-day operations of the apartment building as well as supports the board in the planning and communication activities. Property managers have been identified as important middle actors between policy, technology, residents and their practices in previous research (Peltomaa et al., 2020). In two of the studied housing cooperatives, the property management company was also co-owned by the housing cooperatives, while in others it was selected based on market tendering.

Five of the housing cooperatives are in Helsinki, two in Vantaa and one in Joensuu. The construction year of the buildings ranges from the late-1950s to the early-1990s, and the housing cooperatives vary regarding type and number of buildings. The housing cooperatives had carried out sustainable energy projects, such as installing smart meters and predictive heating systems or larger refurbishment project preparations. We considered the engagement in the projects as an indicator for interest towards sustainable energy solutions and thus a selection criterion to be included in the study.

Our aim was to interview property managers and chairs of the boards from all housing cooperatives, as well as board members and residents from five that represented different sites and sizes. We conducted altogether 50 interviews between December 2019 and May 2020 (see Table 10.1). The interviews took place in the interviewees' homes, in the housing cooperatives' shared spaces or in nearby cafeterias. In addition, since the closures due to the Covid-19 pandemic, almost half of the interviews were done by phone or by video conferencing tools. The interviews lasted from 15 to 95 minutes, the average being around 45 minutes. The semi-structured interviews covered the themes of 1) the personal engagement with energy and main sources of information; 2) the most recent major renovations and activities; 3 ) the planned energy renovations; 4) the collaboration between different actors in these renovations; 5 ) the available information, financial or other support; and 6) the communications and collaboration within housing cooperatives. The interview guide was adjusted to the different types of actors but covered all the themes for each group.

The transcribed interviews were qualitatively coded and analysed based on our theoretical framework. There are many ways of conceptualising practices (see e.g., Gram-Hanssen, 2011). In our study, following Schatzki (2015), we see practices as entities organised by participants' understandings of how to do things, the

Table 10.1 Number of interviews

\begin{tabular}{lllll}
\hline Property manager $^{1}$ & Chair of the board & Board member & Resident & Total \\
\hline 4 & $9^{2}$ & 14 & 23 & 50 \\
\hline
\end{tabular}

${ }^{1}$ Some of the property managers were unwilling to participate in the interview at the time.

${ }^{2}$ In one of the housing cooperatives, both former and recently chosen chairs were interviewed. 
principles and rules they are guided by and normatively prescribed objectives and ends. Moreover, technologies and material arrangements have been considered important especially in practice-based studies on energy and thus also in this study (see Gram-Hanssen et al., 2017; Strengers, 2012).

\section{Results}

\section{The different roles of actors in practices of housing cooperatives}

There are three main categories of actors in the regular housing cooperatives: residents, boards and property managers. ${ }^{2}$ In times of renovation projects, the network extends covering other actors, such as consults, planning offices, technical experts, engineers, builders and building companies, inspectors and public authorities. However, in this section, we focus on the roles of boards, property managers and residents.

Some of the board chairs described themselves as "project managers" having to take care of a number of things related to the daily practices in housing cooperatives, and they considered their active role as critical for day-to-day upkeep, as well as for any improvements, in the housing cooperative. This role also gives them natural leadership in taking the initiative of energy projects. The workload has increased over the years with new requirements on planning and reporting, so the position resembles part-time work and currently many of the chairs get compensated for their time invested. The board members also expected the chair to clearly take the lead and to actively communicate with the property manager. The residents valued the active presence of chairs via regular updates in bulletins and emails.

Board members saw themselves having various roles. Some were actively educating themselves about energy issues, while others considered themselves as mere receivers of the information. This was somewhat in contrast with the expectations that were given to the board by the chairs and property managers, who expected the board members to actively look for information, be interested in learning and put effort into the management activities in the housing cooperative. The residents often considered board members as middlemen who listen to the concerns related to living comfort and technical functioning of the building, though such daily issues are beyond their focus. The studied cooperatives differed greatly regarding the interest of residents joining the board. If the board is passive, it requires constant "pushing" from the property manager - which they necessarily did not have resources for, as they spread their worktime across dozens of apartment buildings.

Property managers were in many cases not expected to take a (pro)active role in energy issues. They were seen as important actors in "keeping the wheels rolling" in general and making sure that everything is functioning well, financially and technically, but the initiatives were expected to come from the boards. One of the chairs even described how they "do the everyday management by themselves" as the property manager only takes care of reports, certificates and 


\section{Senja Laakso and Jani Lukkarinen}

other paperwork. However, if there were any issues, such as unexpectedly high consumption of energy or water, the property managers were expected to raise those and suggest solutions.

Nevertheless, the property managers are the ones with holistic information on the buildings (also in relation to other similar buildings), networks of planning specialists and, in most cases, formal education to evaluate the feasibility of different initiatives. The property managers and management companies thus hold a great potential as they have expertise and experiences from many projects and a large number of housing cooperatives, and they can share the expertise and extended networks among all the cooperatives they work with. Some chairs felt that this potential was largely unexploited and were missing a more proactive hold from their property managers, as otherwise the responsibility lay with the chair and whether they were interested in energy issues or not. In some housing cooperatives, the property managers indeed brought up some suggestions for consideration for the boards about energy management applications, solar panels, ground-source heat pumps or other renewable energies, and the board members valued that. One chair also noted that it does not have to be the property manager, but the companies could host the energy expert that could bring energy issues up in the housing cooperatives when possible.

The property managers interviewed were very cautious about their role, especially in promoting energy renovations (or renovations in general). From their perspective, it was critical that the boards take the active role and responsibility for any decisions made, as they are the ones elected to represent the residents. While some managers were willing to "guide" the board members in decisionmaking and to suggest potential contractors and other actors as they realised that this was something that was needed in the boards, some were more careful due to these juridical issues, liabilities and resources, even if they had the needed expertise (see also Kyrö et al., 2012).

Only a minority of interviewed residents considered community or sustainability as the most important aspects in managing the housing cooperatives, while most of the residents valued comfort of living and economic efficiency. The board members saw the residents have an important role in deciding whether sustainability is an important issue in the housing cooperative or not, as the board is expected to represent the residents and their feedback could trigger more active orientation from the property manager. The residents can also stall the projects they are not engaged in. Generally, the residents did not consider having much say on the energy topics, and their main means of action were providing incremental initiatives and participating in annual meetings. Few wished that the board and the property manager organised more events or other opportunities for them to discuss and become heard on topical issues or coming plans - which could have a positive impact also on the outcome of a project or materialised energy savings (see Heiskanen et al., 2013). However, some of the chairs recognised tensions in engaging residents as much as possible and considered allocating the decision-making solely for the board representing the residents as "less complicated." 


\section{The "critical" practices for sustainable energy in housing cooperatives}

Based on the interviews of actors in housing cooperatives, practices critical for either supporting or preventing engagement with sustainable energy were all not directly related to energy but to the day-to-day activities such as strategic envisioning and planning, dividing work and communicating within the housing cooperative. In the following, we present main findings and examples on the practices of decision-making, planning, counselling and communication.

\section{Practices of decision-making}

The practices of everyday decision-making in housing cooperatives are in principle based on the roles described above. Board holds the main decision-making power, while chair and property manager are mainly responsible for forming the agenda. Residents, however, are not directly engaged in the decision-making activities in regular conditions.

The interest in joining the board differs greatly from one housing cooperative to another. In our interviews, the openness for new things and readiness to experiment were viewed as important characteristics in the board. Some interviewees discussed the community energy projects being envisioned in the boards, which was considered a motivational factor and learning opportunity. However, the board obligations that included long meetings and digesting large amounts of information, were also in constant conflict with their everyday life consisting of other practices, such as working and taking care of the family. In some housing cooperatives and for some board members, it seemed that their traditional role was to participate in the meetings and do what was required - and, in many cases, that was already quite a lot given the planned or on-going renovations and other responsibilities. Therefore, the energy issues were often considered demanding extra time and effort that many board members were not able to provide.

There is, kind of, no room for those non-acute things, or we have been more like "now there is a hole in the wall, or now we fix that pipe" or "now someone said that the clubroom is in a bad condition, we need to do something about it." So, it [energy issues] has not been discussed actively in the board. It could be interesting but I feel that someone should provide a ready solution or a concept for it to proceed. If it is like "should we do something about it," it does not go forward.

(HA2, member of the board)

Further, the existing practices and mandates in the boards were considered an obstacle for taking initiative. Although many interviewees were interested and inspired about energy issues, they were also hesitant about changing practices within the boards, towards being utility providers and having to learn new practices of management and maintenance (see also Shaw and Ozaki, 2016). Similarly, the property managers were reluctant to engage in new practices, as the 


\section{Senja Laakso and Jani Lukkarinen}

existing work practices emphasise the day-to-day management of buildings. Here, the role of the municipal energy companies could be to provide the know-how and technologies for implementing the project and managing the new systems.

we have many buildings and they are of similar age, and the ground is similar as well [...] we envisioned if we could get one big unit [of ground source heat] and maybe even go off-grid [...] it would be possible based on calculations. It is very intriguing idea, but I'd feel a lot better if the local energy company would be involved, as they have the technologies and know-how even if we had our own unit [...] it is quite a management, then.

(HA1, member of the board)

In some cases, there was a contradiction between expectations of boards towards the property manager and vice versa, creating tensions and dysfunctionalities in the decision-making. One of the property managers also raised the issue of timing, as projects promoting energy efficiency can fail, if they fit poorly with the ongoing processes in the housing cooperative, which require long-term planning, while board members might favour more ad-hoc initiatives. Contrary to this, the board members also have power to stall the projects as the decision-making practice favours strong consensus.

Liability is one, if the property manager is very active in promoting a certain solution, it inevitably makes the manager also responsible to some degree and if it blows, well you can imagine who will be blamed. It is very difficult. And it's not only about energy but also many other things in the housing cooperative, the one who brings something on a table is the one to carry the responsibility.

(HA4, property manager)

Finally, the distinction between the residents and the shareholders is crucial for how a housing cooperative works (see also Matschoss et al., 2013). The latter might be investors that do not live in the building but still hold the power of making decisions in the annual meetings or even as board members (three of the interviewed chairs were investors). While the investors were generally considered having an obstructing role when making decisions about the renovations not directly increasing the value of the apartment, the investors might possess better resources to engage in the energy renovation projects and even have previous experience and networks.

\section{Practices of planning}

There are two main devices that housing cooperatives use for the planning of future activities. Legislation obligates the housing cooperatives to prepare an updated five-year maintenance and renovation plan and the board to present the plan to the residents in the annual meeting (Ministry of Justice, 2009), but some 
proactive housing cooperatives have opted for even longer-term plans or housing strategies, where the residents are given a more active role. However, it is typical that the sustainable energy topics do not fit on agenda in either.

In the case study of housing cooperatives, the focus of the mandatory renovation plans is strictly techno-economical, which reflects the normative objectives of professional planning practices in the building sector. According to the interviewees, the main aspects of plans were either related to improving the value of buildings by anticipating renovations or keeping the price of living low (or maximising rent profits) by pushing back investment decisions. The sustainability issues were not on the agenda but were instead considered to be something additional, while the obligatory renovations occupied the attention. As one of the board members noted, even if the energy improvements could reduce the costs of living, it might not be enough to persuade residents to invest in them because of vested short-term interests. Therefore, including sustainability aspects in the planning would provide the board members leverage in considering and suggesting longer-term aspects of, for example, retrofitting as an element of the larger renovations. This also enables criteria other than cost, when recruiting contractors for specific projects.

It is the price. Those energy efficient things are often more expensive. I don't know why, maybe it is the new technology. But then you often think about what the added value is, and it has to be profitable in euros. You don't promote something just based on ideology even if it was important for you. And maybe just, I'm not sure if it was officially brought down but that ground-source heat project, I myself was not excited about that at least, because it was something like 400,000 euros' investment and the payback time was like 40 years [... these are old buildings after all, who knows if they even exist after 40 years as the trend now is to tear down the old and build new instead.

(HA5, member of the board)

Consequently, the long-term strategies offer a more deliberative and inclusive space but face a different type of dynamics. Three of the case study housing cooperatives had prepared strategies (either energy strategy in particular or more general strategy that also includes sustainability topics) that were expected to allow more visionary discussions on the long-term priorities and long-term improvements. However, the interviewed board members, while noting the potential of repositioning energy on the shared agenda of housing cooperatives, were unsure about how the sustainability goal would transform to practice as these are still rather new strategic tools that need operationalisation on a case-by-case basis. The residents were usually involved in the strategy work through questionnaires and workshops that allow voicing concerns and providing feedback, but the energy and sustainability topics are usually not at the top of their priority list but preceded by the mundane issues of convenience, healthiness and cost of living. The housing cooperatives thus lack the capabilities of linking sustainability 
aspects, such as more active management of heating, with comfort and convenience (see also Gram-Hanssen et al., 2017).

in the resident survey, the most important thing was the convenience of living, outdoor areas and the economy of course, I cannot remember if the energy part was asked or what were the responses like, but the energy comes through the economy.

(HA1, chair of the board)

Moreover, the board members viewed the strategies as another administrative document with less practical influence than the long-term renovation plans. The residents did not engage with the strategies as anticipated and the envisioning practices gained no reflection in the interviews. Therefore, rather than activating envisioning or deliberation of sustainable energy topics, the two complementary devices stabilise the existing planning practices in which sustainability plays a minor role.

\section{Practices of counselling}

The obstacles in integrating the sustainable energy issues in the decision-making and planning practices of housing cooperatives are connected to management of available information. The amount of information in the building sector is indeed vast and scattered across different platforms.

Financing the energy projects proved to be a particularly problematic area. There are various municipal, national and EU projects providing temporary aid for energy activities, but these are disconnected from the sphere of housing cooperatives. Some of the board chairs and members were confused about the different alternatives and hoped that they could have an overall image of the feasible solutions and support mechanisms, especially when it comes to sustainability. Furthermore, instead of approaching the apartment building as a whole, service providers and authorities often focus on specific aspects and the responsibility for reaching an optimal result is left to the housing cooperatives.

The property manager brought up these ... electric vehicle charging station aids [...] there are so many kinds of them and new ones emerge all the time. Especially related to cars, there are many mechanisms and, I did not get the whole picture of which ones would be best and most functional for us.

(HA6, member of the board)

Several of the interviewed chairs and board members had been actively educating themselves about energy issues and considered it valuable. Most mentioned peergroups on social media and professional journals as important sources of information, highlighting the importance of both peer and expert support in learning about new technologies and ways to utilise them in practice (see also Karvonen, 2013). Moreover, some had also recently participated in energy expert courses, 
which provided them with basic tools to find out about energy issues and the opportunity to meet technical specialists. They recognised that energy ignorance may lead to for example maintaining old technological constellations, reproducing less-sustainable heating practices and missing potential economic savings. This was illustrated by the case of a housing cooperative shifting to combustionfree ground-source heat pump solution.

Those courses are useful also because you meet people there and have an opportunity to discuss with them, hear about their experiences and things to consider [...] it supports this, provides food for thought for someone like me, not educated in this field. I'd say that through these courses and listening to the experts, it has really improved the understanding of laymen like myself, and strengthened the will to take these issues forward. [...] I heard about a housing cooperative, one of the board members had suggested a groundsource heat pump and the others resisted. So, people have attitudes that reflect the ignorance and lack of information.

(HA3, chair of the board)

The property managers were seen as a potentially important source of information and several board members expected active counselling from the managers. Consequently, some property managers acknowledged this by organising events on energy issues and invited experts to board meetings. Some of the property managers were indeed very educated on energy issues and had a professional background on, for example, energy consultancy. However, this was clearly a minority among the studied housing cooperatives and not all the property managers found resources "to educate" the members of the board. In fact, this is also reflected in the reluctance of managers towards this study focusing on energy issues.

Not surprisingly, several board members and majority of the interviewed residents considered it sufficient to only follow energy-related issues in the news and social media feeds. One of the board members even thought that if they owned a detached home in which they had more power over energy issues, they would think about the topic more actively. Some residents also considered the daily energy practices an important topic to pay more attention to and pointed out that tailored energy tips could be a welcome way for incremental improvements. However, there were also more active residents, who used different specialist sources to verify and critically evaluate the information on the energy projects as well as passive residents who considered energy issues being totally beyond their realm of influence. The engagement with information also reflected the resident's interest in participating with the long-term development of the housing cooperative but none of the studied housing cooperatives was particularly successful in connecting personal energy interests with practices of decision-making and planning.

Many board members hoped for a centralised and independent counselling platform for seeking and finding information (both information and financial), learning about on-going projects and contacting experts. The field of energy 
renovations in the building sector is so complex, that having such a platform would make it a lot easier for board members and property managers to learn about and compare different alternatives and build networks for specific kinds of projects.

\section{Practices of communication}

Critical issues regarding advancing the sustainable energy topics are tied to the practices of communication. There are several areas where insufficient or wrongly positioned communication practices may become an obstacle for sustainability improvements. The topics are often entangled with the medium of communication and issues of inclusion, which should not be overlooked in the discussions on sustainable energy practices.

Already before the Covid-19 disruption, many of the boards had moved their meetings to virtual platforms of email and social media, which have replaced a lot of face-to-face interaction. This shift has accommodated a more pragmatic and strictly topical focus on the hands-on management issues with less room for general discussions on sharing knowledge and experiences about sustainability issues. In several cases, it has also excluded elderly board members who lack the skills to use these tools.

However, especially the communication between boards and residents was seen as a complex task in all of the housing cooperatives. The boards relied to a high degree on "low-tech" means, such as printed notes on the bulletin board, with the chair of the board often being responsible for printing and distributing the notes. Printed materials were considered the equal way of communication, despite it being one-way, minimal and not allowing any conversation among the residents. Many of the interviewed residents also valued the effort, because the bulletins offered clear summaries on decisions and a transparent paper trail to legitimate the actions. Some of the housing cooperatives also published a regular newsletter that included for instance practical tips about recycling but less about energy saving directly as those were considered uninteresting (or at least invisible) for many residents. Further, the board members felt uneasy to ask people to use less water or turn down heating. This highlights the stability of social norms and conventions of, for example, comfort and cleanliness, in mundane energy use (Laakso et al., 2019).

All the housing cooperatives had at least discussed about applying IT platforms for communications and management, but there were no good experiences, as they remain separate from the practices and spaces of everyday communication. Email and social media were seen as more interactive channels in all the housing cooperatives but it was recognised that they could be exclusionary and even become quite off-putting without moderation. One board member notes that not all residents even expect interactive communication. There could thus be a need for deliberation on the goals of communication and whether it is about engaging residents or merely disseminating information, as well as better reasoning for engagement efforts, as described by one of the interviewed board members: 
When I was not in the board I knew nothing. Actually, there was some kind of a survey but it did not come up what it was about and if it was part of some larger project, or why I should respond and take part as a resident. It was just a piece of paper coming by mail and it remained open what it was, what it was related to or anything. From the viewpoint of the resident, you could have hoped for a bit better background or reasoning and like "hi, as a housing cooperative we are going in this direction and this kind of project is being planned, and it is important that as many residents as possible take part." But now it seemed like [...] not so many residents got involved, which is of course a bad thing and we did not get a very wide perspective from the residents.

(HA1, member of the board)

Many interviewees recognise that creating a more collective atmosphere in the building would make communications easier and more inclusive, as people would know each other and talk to each other more openly, which would both raise interest on the matters of the housing cooperative as well as help the information spread. Many residents of the smaller housing cooperatives indeed valued the more informal way of making decisions and solving issues. As noted by one board member, it is easier to say what you think in the laundry room of the building than in the annual meeting. However, this also creates potential new interest conflicts, as loud minorities might end up deciding over the whole community. Some residents, however, found anonymity important when voicing their ideas and opinions. For example, the annual meeting was considered a pressurised situation for queries or statements.

It is easier to ask questions without going to any meeting, those are so oppressive situations. As we do have the internet nowadays and it is a modern way to communicate. So, you could just ask questions and provide suggestions online.

(HA2, resident)

One important line of communication on energy issues is between boards and housing managers, but there are also complicating factors. As the managers' bill for every meeting they join, some of the board members thought that it was best to invite managers only to necessary meetings, which are run as efficiently as possible. This excludes the manager from less formal discussions on, for example, sustainability and thus emphasises their technocratic role. This could also put some pressure on the chair as the link between the board and the property manager in making sure that all actors are on the same page.

Finally, the collaboration was considered important also from the perspective of developing the residential area on more planning related topics, such as dispersed energy and storage or mobility. However, there are no official forums for discussion among housing cooperatives, which meant that unless some chairs of the boards in the area were active, the communication was challenging. The 


\section{Senja Laakso and Jani Lukkarinen}

buildings are also in different stages of their life cycles and thus energy renovations are not topical to all the neighbouring buildings at a certain time. Some of the chairs indeed raised up the need for coordination from, for example, the municipalities in order to improve the collaboration.

\section{Conclusions: towards sustainable energy practices and improved decision-making}

In this chapter, we have approached the positioning of sustainable energy in housing cooperatives from the perspective of practices and actors' roles. Our findings show that the critical practices from the energy policy perspective are not necessarily related to energy as such but to mundane practices, such as those of decision-making, finding and utilising information, planning and communication. In this section, we provide summarising perspectives on how to re-engage housing cooperatives to the energy policies.

The roles and expectations towards different actors can be seen as blurry, which (un)intentionally complicate the sustainable energy improvements in buildings. It is not always clear who should hold the initiative and how the responsibilities are defined in energy investments. For example, the existing working practices and the allocation of liabilities in decision-making may discourage the property managers from taking a more proactive role in promoting sustainable energy, while the board members' initiative in decision-making might rely on this proactivity. Re-defining the role of property managers, who already hold the pragmatic knowledge on the buildings, could support the planning and implementation of sustainable energy solutions. In essence, new incentive structures prioritising sustainable energy improvements and linking them more directly to the management practices in the buildings need to be introduced for contracting to support the inclusion of sustainability in the practices of housing cooperatives' decision-making.

Education is another key area worth policy interest. The voluntary nature of the board implies that while skills related to planning and implementation of sustainable energy solutions are needed, no counselling is required nor readily available. Moreover, the property managers who are central middle-actors often lack needed skills in energy actions (e.g., Peltomaa et al., 2020). Public policy can take a facilitating position by providing tailored information platforms and accessible online and face-to-face courses available for anyone interested in energy issues in the housing cooperative. Making energy information more tangible works as an incentive also for educating the boards of housing cooperatives.

The democratic structure of the housing cooperatives might passivate the residents from committing to sustainability. First, a large share of investors in relation to tenant-owners often reduces motivation in carrying out investments and shortens the timespan of decision-making. The flawed incentive structure could be balanced by stronger public intervention by, for example, obligating energy performance consideration and modelling at the early stages of project planning or as components in the long-term maintenance plans on buildings. Second, the 
participation of residents in energy decision-making could be enhanced by the wider use of housing cooperative strategies as a novel planning device. However, to become effective they need to replace the established practice of planning as merely doing the inevitable and avoiding any extra effort. The actual concerns of residents are also currently undermined, as the strategies lack connection to the daily practices. The strategy work, at the level of the housing cooperatives but also at the level of the state, would indeed benefit from engaging more closely with how present but also future practices in homes steer energy demand and its spatial and temporal dynamics (Strengers et al., 2019). As the capacity of buildings as energy producers and demand response party is strengthened in a changing energy system, the connection of the residents' everyday practices with the systemic level becomes more direct. In addition, based on our findings, engagement of residents by finding varying and more informal means of communication would be crucial in providing acceptability of the projects (see also Kojo et al., in this book). This also requires an understanding of the objectives of communication and whether it is only to spread information or also to support engagement.

The practice approach also emphasises how buildings themselves, as well as existing infrastructure, create material constraints for the energy projects. The buildings are architecturally designed to operate as integrated wholes rather than consisting of modular components that could be developed and renovated separately. These create material baseline conditions, where the energy-related issues in housing cooperatives are distanced from individual residents' sphere of influence and placed on the level of the collective. Further, there are always a limited number of technical combinations available for a specific place and at the specific point of the renovation cycle - and fitting these to social practices is not always straightforward (Shaw and Ozaki, 2016). Recognising the social role of these technologies is an important communicative challenge for housing cooperatives, which can also be approached from the perspective of residential areas or city blocks. In practice, cities and municipalities can operate as facilitators for collaborative planning, co-procurement and peer-to-peer learning on the scale of residential areas. In fact, the on-going renewal of the land-use and building act in Finland is enabling municipalities to take a more proactive role in steering the development in the district and city-block level as well as creating collaborations between building owners and energy companies. This also highlights how not all the changes should be made on a legislative level or at the level of the state but together with municipalities, residential areas, housing cooperatives and other actors.

In conclusion, this chapter has revealed how the sustainable energy decisions are entangled in a complex of practices and materialities within housing cooperatives. Although the governance and maintenance of housing associations, cooperatives or companies might vary across countries, the challenges faced are shared in many contexts also in the Baltic Sea region (Matschoss et al., 2013). A practice-theoretical approach complements the systemic view on energy transitions by focusing on unarticulated gaps in actor roles and sharing of responsibilities oneveryday basis. Further, the practices such as those of decision-making, 


\section{Senja Laakso and Jani Lukkarinen}

planning, counselling and communication require reconfiguration in the level of housing cooperatives, which can be supported by stronger incentives and carefully designed policy interventions, especially by providing more coordinated information management and hands-on support. The practice-theoretical reading positions the housing cooperatives as spaces of policy implementation connecting the ambitious large-scale visions to pragmatic work of reconfiguring the present ways of doing.

\section{Acknowledgements}

This work was supported by the Academy of Finland, under grant number 315898 .

\section{Notes}

1 Housing cooperative (taloyhtiö in Finnish) is by jurisdictional definition a corporation managing the apartments, offices and business premises of a building, where a single share or a group of shares give their owner proprietary rights to specific property and voting rights in the annual meeting. To qualify as a housing cooperative, the total floorspace of apartments must be more than $50 \%$ of the building's overall surface area. Housing cooperatives are a form of collective ownership and decision-making in living environments and vary between country contexts regarding specific rules (Ministry of Justice, 2009).

2 The Board (or the Board of Directors, as defined in the Limited Liability Housing Companies Act) shall see to the administration of the housing company, the appropriate organisation of maintenance of the real estate and of the buildings and other operations. The Board of Directors shall be responsible for the appropriate arrangement of the control of the housing company accounts and finances. The Manager shall see to the maintenance of the real estate and of the buildings and to the executive management of the housing company in accordance with the instructions and orders given by the Board of Directors. The Manager shall see to it that the accounts of the housing company comply with the law and that its financial affairs have been arranged in a reliable manner (Ministry of Justice, 2009).

\section{References}

Gram-Hanssen, K. (2011) Understanding change and continuity in residential energy consumption. Journal of Consumer Culture, 11, Thousand Oaks: SAGE Publications, pp. 61-78. DOI:10.1177/1469540510391725

Gram-Hanssen, K., Heidenstrøm, N., Vitters $\varnothing$, G., Madsen, L. V. and Jacobsen, M. H. (2017) Selling and installing heat pumps: Influencing household practices. Building Research and Information, 45(4), Abingdon: Taylor \& Francis, pp. 359-70. DOI:10.10 $80 / 09613218.2016 .1157420$

Guy, S. and Shove, E. (2000) A Sociology of Energy, Buildings and the Environment. Constructing Knowledge, Designing Practice. London and New York: Routledge.

Heiskanen, E., Johnson, M. and Vadovics, E. (2013) Learning about and involving users in energy saving on the local level. Journal of Cleaner Production, 48, Amsterdam: Elsevier, pp. 241-9. DOI:10.1016/j.jclepro.2012.08.019 
Heiskanen, E., Hyvönen, K., Laakso, S., Laitila, P., Matschoss, K. and Mikkonen, I. (2017) Adoption and use of low-carbon technologies: Lessons from 100 Finnish pilot studies, field experiments and demonstrations. Sustainability, 9(847), p. 847, Basel: MDPI. DOI:10.3390/su9050847

Karvonen, A. (2013) Towards systemic domestic retrofit: A social practices approach. Building Research $\mathcal{E}$ Information, 41(5), Abingdon: Taylor \& Francis, pp. 563-74. DOI :10.1080/09613218.2013.805298

Kivimaa, P. and Kern, F. (2016) Creative destruction or mere niche support? Innovation policy mixes for sustainability transitions. Research Policy, 45(1), Amsterdam: Elsevier, pp. 205-17. DOI:10.1016/j.respol.2015.09.008

Kivimaa, P., Primmer, E. and Lukkarinen, J. (2020) Intermediating policy for transitions towards net-zero energy buildings. Environmental Innovation and Societal Transitions, 36, Amsterdam: Elsevier, pp. 418-432. DOI:10.1016/j.eist.2020.01.007

Kyrö, R., Heinonen, J. and Junnila, S. (2012) Housing managers key to reducing the greenhouse gas emissions of multi-family housing companies? A mixed method approach. Building and Environment, 56, Amsterdam: Elsevier, pp. 203-10. DOI:10.1016/j.buildenv.2012.03.008

Laakso, S., Jensen, C. L., Vadovics, E., Apajalahti, E.-L., Friis, F. and Szőllőssy, A. (2019) Towards sustainable and sufficient energy consumption: Challenging heating-related practices in Denmark, Finland and Hungary. In Proceedings of the $19^{\text {th }}$ European Roundtable for Sustainable Consumption and Production. Circular Europe for Sustainability: Design, Production and Consumption, Amsterdam: Elsevier, pp. 25-40.

Lazarevic, D., Kivimaa, P., Lukkarinen, J. and Kangas, H. L. (2019) Understanding integrated-solution innovations in sustainability transitions: Reconfigurative buildingenergy services in Finland. Energy Research and Social Science, 56, Amsterdam: Elsevier, p. 101209. DOI:10.1016/j.erss.2019.05.019

Macrorie, R., Foulds, C. and Hargreaves, T. (2015) Governing and governed by practices: Exploring interventions in low-carbon housing policy and practice. In Strengers, Y. and Maller, C. (eds.), Social Practices, Intervention and Sustainability. Abingdon: Routledge, pp. 95-111.

Matschoss, K., Atanasiu, B., Kranzl, L. and Heiskanen, E. (2013) Energy renovations of EU multifamily buildings: Do current policies target the real problems? ECEEE SUMMER STUDY Proceeding, pp. 1485-96. Online: https://www.eceee.org/library/ conference_proceedings/eceee_Summer_Studies/2013/5b-cutting-the-energy-use-of -buildings-policy-and-programmes/energy-renovations-of-eu-multifamily-buildingsdo-current-policies-target-the-real-problems/ (Accessed on 2021-05-14).

Ministry of Justice (2009) Limited Liability Housing Companies Act, 1599/2009. Online: https://finlex.fi/en/laki/kaannokset/2009/en20091599 (Accessed on 2021-05-14).

Pahkala, T., Uimonen, H. and Väre, V. (2018) Joustava ja asiakaskeskeinen sähköjärjestelmä; Älyverkkotyöryhmän loppuraportti (Issue 33/2018). URN:ISBN:978-952-327-346-7.

Palm, J. (2013) Energy efficiency in tenant-owners' residences: The process of going from objective to implementation. Housing Studies, 28(1), Abingdon: Taylor \& Francis, pp. 57-73. DOI:10.1080/02673037.2013.729266

Palm, J. and Reindl, K. (2018) Understanding barriers to energy-efficiency renovations of multifamily dwellings. Energy Efficiency, 11(1), New York: Springer, pp. 53-65. DOI:10.1007/s12053-017-9549-9

Peltomaa, J., Mela, H. and Hildén, M. (2020) Housing managers as middle actors implementing sustainable housing policies in Finland. Building Research $\mathbb{E}$ 


\section{Senja Laakso and Jani Lukkarinen}

Information, 48(1), Abingdon: Taylor \& Francis, pp. 53-66. DOI:10.1080/096132 18.2019 .1655629

Schatzki, T. R. (2015) Practices, governance and sustainability. In Strengers, Y. and Maller, C. (eds.), Social Practices, Intervention and Sustainability. Abingdon and New York: Routledge, pp. 15-30.

Schatzki,T.R.(2017)Practicesandpeople.TeoriaePráticaEmAdministração,7(1), JoãoPessoa: Universidade Federal da Paraíba, pp. 26-53. DOI:10.21714/2238-104X2017v7i1-32735

Shaw, I. and Ozaki, R. (2016) Emergent practices of an environmental standard. Science, Technology, Eु Human Values, 41(2), Thousand Oaks: SAGE Publications, pp. 219-42. DOI:10.1177/0162243915589765

Shove, E. and Pantzar, M. (2005) Consumers, producers and practices: Understanding the invention and reinvention of Nordic walking. Journal of Consumer Culture, 5(1), Thousand Oaks: SAGE Publications, pp. 43-64. DOI:10.1177/1469540505049846

Strengers, Y. (2012) Peak electricity demand and social practice theories: Reframing the role of change agents in the energy sector. Energy Policy, 44, Amsterdam: Elsevier, pp. 226-34. DOI:10.1016/j.enpol.2012.01.046

Strengers, Y., Pink, S. and Nicholls, L. (2019) Smart energy futures and social practice imaginaries: Forecasting scenarios for pet care in Australian homes. Energy Research $\mathbb{E}$ Social Science, 48, Amsterdam: Elsevier, pp. 108-15. DOI:10.1016/j.erss.2018.09.015

Welch, D. and Yates, L. (2018) The practices of collective action: Practice theory, sustainability transitions and social change. Journal for the Theory of Social Behaviour, 48(3), Hoboken: Wiley-Blackwell, pp. 288-305. DOI:10.1111/jtsb.12168

Wolff, A., Weber, I., Gill, B., Schubert, J. and Schneider, M. (2017) Tackling the interplay of occupants' heating practices and building physics: Insights from a German mixed methods study. Energy Research $\mathcal{B}$ Social Science, 32, Amsterdam: Elsevier, pp. 65-75. 